\title{
Evaluation of Small and Medium Sized Enterprise Innovation Performance Growth in Malaysia
}

\author{
Rashidah Binti Mohamad Ibrahim ${ }^{1}$, Abasiti Victor Abraham ${ }^{2}$ \& Wan Abd Aziz Bin Wan Mohd Amin ${ }^{1}$ \\ ${ }^{1}$ Faculty of Economics \& Management Science, Universiti Sultan Zainal Abidin, Gong Badak Campus, Kuala \\ Terengganu, Terengganu, Malaysia \\ 270 Nelson Mandela Road, Uyo, Akwa lbom State, Nigeria \\ Correspondence: Abasiti Victor Abraham, 70 Nelson Mandela Road, Uyo, Akwa lbom State, Nigeria. E-mail: \\ abasitiabraham@gmail.com
}

Received: August 06, 2018

Accepted: August 31, 2018

Online Published: September 7, 2018

doi:10.5539/ijbm.v13n10p161

URL: https://doi.org/10.5539/ijbm.v13n10p161

\begin{abstract}
Innovation is defined as a natural renewable source accessible to all restricted only by human effort. It is also affirmed that innovation create a positive impact of the organization capability. Based on the current situation in Malaysia, it's established that SME's has been undergoing challenges that have reduce their capability, sustainability and growth. These issues have created a negative impact of the SME's and also in the Malaysia economy. Hence, for SME's to be strengthen and to overcome their problems, there should be a drastic change or modification to be experienced in Malaysia SME's which will enhance their capability towards innovation performance growth. As such this study investigates the innovation practices amongst the SMEs, in order to enhance their business growth performance in the Malaysian market. Data from a sample of 413 respondents from SMEs in the construction, service and manufacturing sectors was collected by means of a structured questionnaire. The sampling technique/procedure used was the stratified random sampling in other to analyze the hypothesis model. The result of the findings indicated that there is a positive relationship between organization culture and human capital towards innovation performance growth with organizational culture having the strongest coefficient. The findings as well enlighten small and medium sized firms as well as policy makers that innovation is an essential tool in the present day business doings. In conclusion, further studies should examine how small and medium sized firms can make a choice from a range of possibilities for innovation sources before they carry out the real innovation.
\end{abstract}

Keywords: Human capital, innovation performance, organization culture, small and medium sized enterprise (SME)

\section{Introduction}

Innovation is considered as a vital tool that help to promote opportunities of new business growth and market (Atalay, Anafarta and Sarvan 2013). There has been a remarkable increase in business and organization expansion as a result of innovation implementation (Kafetzopoulos and Psomas, 2015). Due to the high level of competition amongst SME's in Malaysia and globally, it is essentials for organization to enhance their strategic innovation to suit their organization culture as well as employees with the purpose of enhancing and maintaining their flow of performance growth (Charles and Karanja, 2014). Innovation is important to organization and which is seemed as one of the strategies that positioned organization at the high pace of performance. According to Sabouri, Ghobakhloo, Hong and Zulkifli (2011), innovation is defined as a natural renewable source accessible to all restricted only by human effort. It is also affirmed that innovation create a positive impact of the organization capability (Schiuma and Moustaghfir, 2013). According to Saunila, Pekkola and Ukko (2014), SMEs contributes greatly to the economy of Malaysia \& the Tenth Malaysia Plan supports this by stating that $99.2 \%(518,996)$ of the entire recognized businesses are SMEs while $0.8 \%(4,136)$ are big businesses in Malaysia (Abdulsaleh and Worthington, 2013).

Malaysian SME's organizations perceived that there is an important impact in promoting their innovation in order to sustain their business growth effectively (Ferri and Mohd, 2012). As indicated by Halim, Ahmad, Ramayah and Hanifah, (2014) Economic Transformation Programme Report, Malaysia has planned effectively on transforming their business operation in order to strengthen and positioned their SME's performance growth 
at a high pace which will help to sustain the organization lifespan effectively. Even the Malaysian government have carved out their strategies that will help to promote the SME's so as to reach their maximum level of innovation performance by 2020. In addition, the SME's have been contributing tremendously towards to the development of Malaysia economic growth.

Based on the Malaysian statistical data, the services industry such as manufacturing has increased by $7.2 \%, 6.2 \%$ increase in agriculture sectors, and $6.9 \%$ increase in transportation industries which has amount to the development of the country GDP (Pirayeh, Mahdavi \& Nematpour, 2011). On the other hand, when comparing the SME's of Malaysia to other Asian countries, study shows that SME's in Malaysia contributes slightly low towards their GDP compared to other Asian countries (Asian SME Corporation, 2015). In 2015 toward 2016, the contribution of SMEs to the GDP growth of Malaysia decline from 5.7\% in the 1st quarter of 2015 to $4.9 \%$ in 2nd quarter of 2015, and went from $4.7 \%$ in the 3rd quarter of 2015 to $4.5 \%$ in the 4 th quarter. As of 1 st quarter of 2016 it dropped to $4.2 \%$. This decrease has significantly created a negative impact concerning development of SME's in Malaysia financial growth and performance (SME Corporation Malaysia, 2015).

Thus, in order for Malaysian SMEs to succeed in dealing with these issues/challenges there have to make a radical adjustment in their practice. As such this research looks into providing empirical evidence on the following aim (objective): to ascertain the relationship between organization culture \& human capital towards innovation performance growth.

The following is how this paper is being organized: introduction of the study, literature review pertaining to the variables are discussed together with the development of the hypothesis as well as the conceptual framework. Likewise, the study methodology, data collection \& data analyses is being explained. As well, empirical findings with respect to the hypotheses tested was revealed \& explained. Finally, limitations of the study, future study and the paper conclusion is being stated.

\section{Literature Review}

In this section the key variables are deliberated as well as detailed, the variables include organizational culture \& human capital. Apart from that, a general idea of Innovation performance background is being presented for a more desirable/satisfactory understanding of innovation practices amongst the Small and Medium Enterprises (SMEs) with the aim of enhancing their business growth performance in the Malaysian market.

\subsection{Small and Medium Enterprises (SMEs) in Malaysia}

In Malaysia perspective, Small and Medium-Size Enterprises (SMEs) is explain broadly using 2 classifications, that is:

- Manufacturing: Sales turnover not exceeding RM50 million OR full-time employees not exceeding 200 workers.

- Services \& other sectors: Sales turnover not exceeding RM20 million OR full-time employees not exceeding 75 workers (SME Corp Malaysia, 2015).

The details by size of operation are as follows;

Table 1. SME Corp Malaysia (2015)

\begin{tabular}{lll}
\hline Category & Small & Medium \\
\hline Manufacturing & $\begin{array}{l}\text { Sales turnover from RM300, 000 to less than RM15 } \\
\text { million or full-time employees from 5 to less than 75. }\end{array}$ & $\begin{array}{l}\text { Sales turnover from RM15 million to not exceeding } \\
\text { RM50 million or full-time employees from 75 to not } \\
\text { exceeding 200. }\end{array}$ \\
$\begin{array}{ll}\text { Services and other } \\
\text { sectors }\end{array}$ & $\begin{array}{l}\text { Sales turnover from RM300, 000 to less than RM3 } \\
\text { million or full-time employees from 5 to less than 30. }\end{array}$ & $\begin{array}{l}\text { Sales turnover from RM3 million to not exceeding } \\
\text { RM20 million or full-time employees from 30 to not } \\
\text { exceeding 75. }\end{array}$ \\
\hline
\end{tabular}

$97 \%$ of registered businesses are known to be SMEs in Malaysia. And they contributes almost thirty-six percent GDP to the country, sixty-five percent employment to the country \& approximately eighteen percent of the country's exports. SMEs in Malaysia has remained the basic/principal economic transformation of Malaysia. Dato Hafsah Hashim (chief executive of SMEs Corporation Malaysia) stated in an event done by the New World Bank Group Knowledge \& Research Hub in Kuala Lumpur working together with the Trade \& Competitiveness Global Practice that "In relation to statistics, SMEs are very important \& that they bring about the strength/support of the country's economy" (The world bank, 2016). 
The existence of SME's in Malaysia is considered vital and they are being encouraged by government for their expansion and development in order to yield a high revenue for the organization \& improvement of Malaysia economy (Ciesielska \& Iskoujina, 2012). The young entrepreneurs start their business life with SME's and it is seen as a starting point for every entrepreneur who has the capability and creativity to explore ideas and to generate income for their ideas (Sherlock and Lambkin, 2013). Based on the census contribution and assessment in 2012, it confirmed that Malaysia SME's (32\%) has been recorded low growth compared to foreign Asian countries such as Japan and China (55\%) as a result of exclusive control of operation, which has reduced their impact of innovation performance and also reflect poorly to their country economy (Rosli, 2013; Hajar 2015). However, Malaysia has set their priority of quality or attainment in order to boost their SME's effectively. This will increase their local business operation prospective as well increase their organization globally (Sattari, 2013).

\subsection{Innovation Performance}

Innovation performance is the continuous process that is required for the success of the organization throughout the business operation to keep strengthening the growth (Haron, Said, Jayaraman and Ismail, 2013). However, innovation and performance has a strong relationship that do help most organization with regard to productivity and growth (Rahman and Ramos, 2014). It's essential to highlight the innovation dimension that contributes to the development of innovation performance for any organization in Malaysia. There are, product, process and market innovation. Product innovation is defined a process of generating or implementing a new idea of products from a new material in order to create an existing product to meet up with the customer satisfaction and as well increase sales performance (Ratnasingam, 2013). Implementation of new product deals on satisfying the existing and potential markets effectively (Saunila and Ukko, 2011). Process innovation is defined as a process that deals on improving and reconstructing a business operation process in order to suit its current market values and segmentation (Mwangi and Ngugi, 2014). It is concluded that process innovation has a strong impact on the product and also its innovation performance. Sun, Wong, Zhao and Yam, (2012) affirmed that market innovation focuses on the market selection and mix so as to boost its customer satisfaction and values which will increase their purchasing decision making. There should be a continuous market innovation if an organization wants to sustain their performance growth effectively (Koe and Majid 2013). According to Surin and Wahab (2013), they asserted that market innovation involves or plays a part in developing the brand \& product image and enhance their innovation performance growth as it will increase their brand awareness and publicity efficiently. It is also significant as it helps to fulfil the market needs and also provides opportunities for markets (Madhoushi, Sadati, Delavari, Mehdivand and Mihandost, 2011). It is confirmed that market innovation has an impact towards promoting the performance growth. Organization that focuses on innovation always excel in their performance efficiently (Wang and Yen, 2012). It is very important for a business to be innovative in Malaysia for the reason that development of their economy is dependent on industrial growth, it is as well a force that drives social development (Dastgerdi, 2012). Presently businesses are not really focused on cutting cost but rather heading for innovation to achieve a long time success (Mwangi and Ngugi, 2014).

\subsection{Organizational Culture towards Innovation Performance}

This is a process whereby shared beliefs, assumptions and values rules the way people act in the organizations (Hutter, Hautz, Repke and Matzler, 2013). These shared beliefs, assumptions and values has an impact on people in the organization in such a way that it decides how people should be dress, behave, \& do their jobs. Organization culture deals on the effective innovation for performance growth and which requires human capital and effective organizational culture in order to establish a successful trends of performance (Rahman and Ramos, 2013). According to Abdul and Tasmin (2013), organization culture is defined as a process that influences positivity of innovation and creativity so as to enhance the organization performance. However, organization culture could be ascertained from their employee's behaviors and action, which reflect either negatively or positively towards their organization culture (Vahter, Love and Roper, 2012). It is indeed a shared social knowledge between the management and employees in an organization and which helps to promote their values, and norms that formulate the attitude and behaviors of their human capital effectively (Saunila and Ukko, 2012).

Organization culture has an impact on promoting the innovation performance as they have designated their strategies, goal and values, which is considered as their standard to be followed. This culture will promote the organization performance and when it is implemented with different strategies as sort of innovation, it will yield a high level of performance for the organization (Wang, 2012; Hussain, Ismail and Shah, 2015). According to Halim, Ahmad, Ramayah, Hanifah, Taghizade and Mohamad (2015) innovation performance and culture has a strong relationship as the required each other skills in order to excel in their respective tasks accordingly. Finally, culture of organization promote innovation performance regardless of its work climate. Culture create a positive 
impact toward the development of innovation performance growth in SME's Malaysia (Wang, 2012).

\subsection{Human Capital towards Innovation Performance}

This measures the benefit provided by an employee's skills/abilities. The idea behind human capital acknowledges that, not every labour is equal in value \& to improve the quality of an employee you train or invest in them; the knowledge, education level \& skills of employees provides benefits to the employers (Maes and Sels, 2014). Employees are the human capital and they are expected to be satisfied in order to strategize an adequate idea that will help to strengthen the performance of an organization effectively (Kuswantoro, 2012). According to Alam, Bhuiyan, Jani and Wel (2016), human capital incorporates good set of skills, understanding/knowledge, introduction of something new or different (innovativeness) as well as capability of carrying out jobs which will create a positive impact on the performance growth of SME's. Employees are the key operation of any organization and they should be considered essential as they provide innovative ideas, strategies, knowledge, skills and behaviours that help to boost performance growth of SME's (Fard, Mansor, Mohamed, \& Bahru, 2011). Businesses that put innovation on human capital first as well as supports it do have increase in terms of their performance year to year. Previous research's regarding the impact of human capital development on SMEs performance is not conclusive. A case in point, according to Oforegbunam \& Okorafor, (2010) which looked into the impacts of this human capital development on SMEs performance in West Africa. The findings of the study indicated that improved human capital development by the selected SMEs resulted in significant increase in performances. In addition, job training was seen to be the most significant choice when it comes to human capital development for SMEs in order to improved performance. Another study carried out by Fatoki (2011) as well looked into the effects of human, social \& financial capital on the performance of SMEs in South Africa. The findings of the study showed that there's a positive connection amid human capital \& performance of Small and Medium-Sized Enterprises. Another affirmation from Datta (2005) stated that the concept of human capital has been seen, among various businesses to be positively affecting innovation performance.

\subsection{Conceptual Framework}

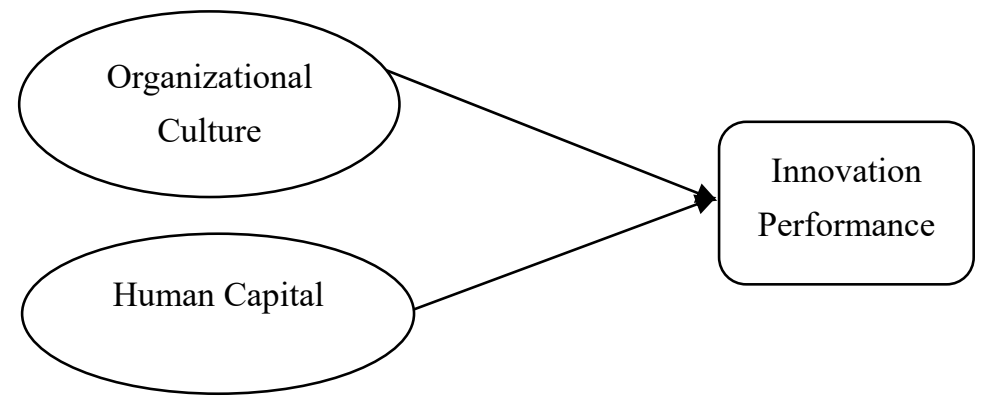

Figure 1. Conceptual Framework

Source: Papadakis, (1998), Peterson, Smith, Martorana \& Owens, (2003), Chandler and Hanks, (2001); McPherson, (2000).

The Conceptual framework of the study established from the literature review which shows the relationship between Organizational Culture \& Human Capital towards Innovation Performance Growth.

\section{Methodology}

\subsection{Study Setting and Sampling}

The research areas were all the SME's in Malaysia from the four (4) regions (East coast, Central, South and North of Malaysia). There are 645,136 registered SMEs in Malaysia (SME Corp. Malaysia, 2014). There are five sectors in Malaysian SMEs but three sectors are chose for this study for two reasons. First, there are one of the major contributors to the economy. Secondly, is the most susceptible to globalization and they are high in innovation. Therefore services, manufacturing and construction sectors were chosen for this research study. The sample population was selected using stratified random sampling. This sampling technique is useful when the population is heterogeneous in the variables or characteristics under study and separates the population into two or more significant and relevant strata (Burns 2000).

From the study area, the sample population was categorize into three sectors. Each sector was randomly selected to enhance the probability of obtaining a representative sample so as to avoid bias. The selection process, consisted of 2 service sector, 2 manufacture and one construction and that was a total of 5 sectors. This survey 
method was preferable because it helped the researcher in communicating efficiently with the employees and also helped to perceive their view concerning innovation performance growth amongst Small and medium size firms in Malaysia. Therefore, all SMEs employees were selected as the sample population.

Furthermore, the sample size for this research was 420. However, 500 closed-ended questionnaires were distributed out among the respondents for the reason that self-administered questionnaires do has limitations for instance non-response. This was to increase the chance of getting the 420. The questionnaires was distributed personally to the SMEs managers' in-charge with briefly explaining the objectives \& variables of the study who then shares it among their employees. From the 500 questionnaires distributed out, only 442 was returned \& 413 questionnaires were deem to be used.

\subsection{Pilot Testing}

This was carried out with the intention of investigating the survey questions with a minimum number of sample, in order to test the survey construction, whether it's in line with the research objective as well whether the respondents simply can understand the given questionnaire. This procedure helped to promote the researcher propensity towards analyzing the feedback received from the respondents before the full-scale research to be undertaken. The researcher adopted a self-administered survey analysis and the pilot study was conducted in June 2017 with 60 questionnaires distributed and received amongst the SME's companies in selected construction, service and manufacturing SMEs Company. SPSS version 23.0 for windows was used to analyzed the data, the finding gotten showed that the questionnaire were valid \& reliable. The values of the Cronbach's alpha showed all the variables had good measurement of reliability exceeding Leong (2010) 0.6 benchmark. The test for Normality indicated that the data were distributed normally \& also to confirm the data was normal skewness \& kurtosis analyses was done. Lastly result for the linear regression analysis was seen to be without multicollinearity.

\subsection{Research Instruments}

The scales used in this study were adapted from established instruments which has proven reliability and validity. Since they were originally worded in English, translation to Malay language was carried out as the respondents were predominantly Malay and majority from low to middle management. In order to guarantee cross-linguistic quality, these translated items were then translated back into English following the method suggested by Brislin (1970).

There is a 4 parts research instrument which includes: demographic information and three scales measuring Organization Culture, Human Capital and Innovation Performance Growth. Which made use of five-point Likert scales that range between (1) strongly disagree to (5) strongly agree.

Table 2. Summary of Survey Instruments

\begin{tabular}{|c|c|c|c|}
\hline Construct & $\begin{array}{l}\text { Item } \\
\text { Quantity }\end{array}$ & Scale & Source \\
\hline $\begin{array}{l}\text { Innovation } \\
\text { Performance }\end{array}$ & 20 & $\begin{array}{l}\text { 5-point } \\
\text { Likert }\end{array}$ & $\begin{array}{l}9 \text { questions were identified from Yahya Darwish Yahya Al-Ansari (2014) and } 11 \text { questions } \\
\text { were adopted form Abdiaziz Mohammed Abdi (2013). }\end{array}$ \\
\hline $\begin{array}{l}\text { Organisation } \\
\text { Culture }\end{array}$ & 20 & $\begin{array}{l}\text { 5-point } \\
\text { Likert }\end{array}$ & $\begin{array}{l}10 \text { questions were identified from Surin and Wahab (2013) and } 10 \text { questions were adopted } \\
\text { form Ratnasingan, (2013) for empowerment. }\end{array}$ \\
\hline Human Capital & 20 & $\begin{array}{l}\text { 5-point } \\
\text { Likert }\end{array}$ & $\begin{array}{l}8 \text { questions were identified from Hajar (2015) and } 2 \text { item were adapted from Masood 2010. } 10 \\
\text { questions were adopted form Doug Tucker (2014). }\end{array}$ \\
\hline Total & 60 & & \\
\hline
\end{tabular}

\section{Results/Discussion}

\subsection{Respondents Profile}

From the 413 respondents, the sample was dominated by the male counterpart with majority of the respondents being Malays. $77.5 \%$ respondents from the Lower Management dominated the workforce, with only $19.1 \%$ being the middle management. Majority of the respondents (98.8\%) have completed their tertiary level of education while the remaining $1.2 \%$ has not achieved educational qualifications. $63.0 \%$ of the respondents earned a monthly income bracket under RM2500. Small size firms dominated the enterprise size with $54.5 \%$ whereas the 
$45.5 \%$ were the medium size firms.

Table 3. Demographic profile of respondents

\begin{tabular}{|c|c|c|}
\hline Demographics & Frequency $(\mathrm{N}=413)$ & Percentage (\%) \\
\hline \multicolumn{3}{|l|}{ Gender } \\
\hline Male & 229 & 55.4 \\
\hline Female & 184 & 44.6 \\
\hline \multicolumn{3}{|l|}{ Race } \\
\hline Malay & & 53.5 \\
\hline \multicolumn{3}{|l|}{221} \\
\hline Chinese & 132 & 32.0 \\
\hline Indian & 53 & 12.8 \\
\hline Others & 7 & 1.7 \\
\hline \multicolumn{3}{|l|}{ Age Group } \\
\hline 25 years old and below & 172 & 41.6 \\
\hline $26-35$ years old & 153 & 37.0 \\
\hline $36-45$ years old & 68 & 16.5 \\
\hline Above 46 years old & 20 & 4.8 \\
\hline \multicolumn{3}{|l|}{ Marital Status } \\
\hline Married & 230 & 55.7 \\
\hline Single & 175 & 42.4 \\
\hline Widow / Widower & 8 & 1.9 \\
\hline \multicolumn{3}{|l|}{ Work Positions } \\
\hline Top Management & 14 & 3.4 \\
\hline Middle Management & 79 & 19.1 \\
\hline Lower Employee & 320 & 77.5 \\
\hline \multicolumn{3}{|l|}{ Education Levels } \\
\hline $\mathrm{PhD}$ & 2 & 5 \\
\hline Masters & 7 & 1.7 \\
\hline Bachelor's Degree & 93 & 22.5 \\
\hline Diploma & 125 & 30.3 \\
\hline Certificate & 87 & 21.1 \\
\hline STPM & 94 & 22.8 \\
\hline No Education & 5 & 1.2 \\
\hline \multicolumn{3}{|c|}{ Tenure of Work in The Present Employment } \\
\hline Less than 5 years & 241 & 58.4 \\
\hline $5-10$ years & 94 & 22.8 \\
\hline $11-15$ years & 43 & 10.4 \\
\hline $16-20$ years & 20 & 4.8 \\
\hline Above 20 years & 15 & 3.6 \\
\hline \multicolumn{3}{|l|}{ Income Level } \\
\hline Under RM2500 & 260 & 63.0 \\
\hline RM2501-RM3500 & 98 & 23.7 \\
\hline RM3501-RM4500 & 40 & 9.7 \\
\hline RM4501-RM5500 & 9 & 2.2 \\
\hline RM5501 and above & 6 & 1.5 \\
\hline \multicolumn{3}{|c|}{ In Which Sector is Your Firm } \\
\hline Manufacturing & 144 & 34.9 \\
\hline Service & 204 & 49.4 \\
\hline Construction & 65 & 15.7 \\
\hline \multicolumn{3}{|l|}{ Enterprise Size } \\
\hline Small enterprises & 225 & 54.5 \\
\hline Medium enterprises & 188 & 45.5 \\
\hline
\end{tabular}

Note. $\mathrm{N}=$ Number of respondents. 


\subsection{Descriptive Statistics}

Computation of Means \& standard deviations were presented. The variables mean scores were above the midpoints, innovation performance had a mean scores of 3.51, 3.62 mean score for human capital and 3.59 mean scores for organizational culture on the five-point scale, this means that the respondents were midpoint agreeable with the survey items variables.

Table 4. Descriptive statistics

\begin{tabular}{lll}
\hline Construct $(\mathrm{N}=413)$ & Mean & Standard Deviation \\
\hline Innovation Performance & 3.51 & 0.50 \\
Organizational Culture & 3.59 & 0.51 \\
Human Capital & 3.62 & 0.50 \\
\hline
\end{tabular}

\subsection{Correlations between Dependent and Independent Variables}

Pearson Correlation analysis was carried out in order to analyze the relationship between the independent variables i.e. organizational culture and Human capital towards dependent variable (innovation performance) efficiency. The findings revealed that all of these predictor variables were found to be significantly and positively correlated to each other. Correlations among these variables were in the category of very strong associations see table 5 .

Table 5. Pearson correlations analysis among variables

\begin{tabular}{llll}
\hline & Innovation Performance & Organizational Culture & Human Capital \\
\hline Innovation Performance & 1 & & \\
Organizational Culture & $.751^{* *}$ & 1 & $.910^{* *}$ \\
Human Capital & $.726^{* *}$ & & 1 \\
\hline Note. $* *$ Correlation is significant at the 0.01 level (2-tailed).
\end{tabular}

\subsection{Reliability Test}

Cronbach alpha coefficient which is the most important test for reliability consistency was employed to measure the internal consistency of the instruments used. As shown in Table 6 the Cronbach alpha test showed values ranging from 0.885 (Innovation Performance variable) to 0.907 (Organizational Culture variable). Therefore, the Cronbach's alphas for these variables were well above the minimum acceptable reliability of 0.70 (Sekaran \& Bougie, 2010) which indicated good internal consistency.

Table 6. Cronbach's coefficient alpha of the variables

\begin{tabular}{lll}
\hline Variables & No. of Items & Cronbach's Alpha \\
\hline Innovation Performance & 20 & 0.885 \\
Organizational Culture & 20 & 0.907 \\
Human Capital & 20 & 0.895 \\
\hline
\end{tabular}

\subsection{Factor Analysis}

Confirmatory factor analysis (CFA) was carried out independently on these variables to allow the researcher test the hypothesis that a relationship between observed variables \& their underlying latent constructs exists. Factor analysis conducted on innovation performance generated 5 factors extracted with the Cumulative $\%$ of 67.40 i.e. this 5 factors explained $67 \%$ of the total variance. The 5 factors were above the eigenvalues of 1 and other factors were below so they were not extracted. The Kaiser-Meyer-Olkin measures of sampling adequacy was 0.816 indicating that the items were strongly interrelated and shared common factors. Significant Bartlett's Test (Chi square $=3153.946, \mathrm{p}<0.001$ ) suggested that significant correlation matrix among the data and factor analysis for innovation performance was considered appropriate to be conducted.

Factor analysis carried out on organizational culture likewise generated 5 factors extracted with the Cumulative \% of 63.47 i.e. this 5 factors explained $63 \%$ of the total variance. The 5 factors were above the eigenvalues of 1 and 
other factors were below so they were not extracted. The Kaiser-Meyer-Olkin measures of sampling adequacy was 0.799 indicating that the items were strongly interrelated and shared common factors. Significant Bartlett's Test $($ Chi square $=4163.539, \mathrm{p}<0.001)$ suggested that significant correlation matrix among the data and factor analysis for organizational culture was considered appropriate to be conducted. Last but not least, factor analysis on human capital indicated 5 factors extracted, explaining a total variance of $65.87 \%$ with an eigenvalue greater than 1. The Kaiser-Meyer-Olkin measures of sampling adequacy was 0.796 with Bartlett's Test of Sphericity indicting $($ Chi square $=4349.588, \mathrm{p}<0.001)$.

\subsection{Multiple Regression}

This test was carried out to learn more about the relationship between the independent/predictor variables and the dependent/criterion variable. And the result of the test indicated that the overall regression model is a good fit for the data and the independent variables statistically significantly predict the dependent variable. The findings were discussed as follows:

As showed in Table 7 the model was considered good with adjusted $\mathrm{R}^{2}$ at 0.575 indicating that a moderate $57.5 \%$ of the variability in innovation Performance Growth has been explained by Human Capital, and Organizational Culture.

Table 7. Model summary of human capital, and organizational culture on innovation performance growth

\begin{tabular}{lllll}
\hline Model & $\mathrm{R}$ & $\mathrm{R}$ Square & Adjusted R Square & Std. Error of the Estimate \\
\hline 1 & $.758^{\mathrm{a}}$ & .575 & .572 & .33217 \\
\hline
\end{tabular}

a. Predictors: (Constant), Human Capital, Organizational Culture

Result from ANOVA (see Table 8) showed that $\mathrm{F}$ value was significant at $\mathrm{F}(2,410)=276.794, \mathrm{p}<0.001$.

Table 8. ANOVA ${ }^{\mathrm{a}}$

\begin{tabular}{lllllll}
\hline Model & & Sum of Squares & df & Mean Square & F & Sig. \\
\hline 1 & Regression & 61.081 & 2 & 30.540 & $.000^{\mathrm{b}}$ & \\
& Residual & 45.238 & 410 & .110 & & \\
& Total & 106.318 & 412 & & \\
\hline
\end{tabular}

a. Dependent Variable: Innovation Performance Growth.

b. Predictors: (Constant), Human Capital, Organizational Culture.

Coefficients (see Table 9) indicated that Organizational Culture \& Human Capital was significant to Innovation Performance Growth at beta $=0.522, \& 0.251$ respectively $p<0.001$. The standardized coefficients shows that organizational culture has the standardized coefficient with the largest absolute valve which explains the greatest amount of the unique variance i.e. organizational culture has the strongest coefficient.

Table 9. Coefficients ${ }^{\mathrm{a}}$

\begin{tabular}{|c|c|c|c|c|c|c|c|c|}
\hline \multirow[b]{3}{*}{ Model } & \multirow{2}{*}{\multicolumn{2}{|c|}{$\begin{array}{l}\text { Unstandardized } \\
\text { Coefficients }\end{array}$}} & \multirow{3}{*}{$\begin{array}{l}\text { Standardized } \\
\text { Coefficients } \\
\text { Beta }\end{array}$} & \multicolumn{5}{|c|}{$95.0 \%$ Confidence Interval for } \\
\hline & & & & & $\underline{B}$ & & Corre & ions \\
\hline & B & Std. Error & & $\mathrm{t}$ & Sig. Lower Bound & Upper Bound & Zero- & lerPartialPart \\
\hline 1(Constant) & .748 & .120 & & & 1.000 .513 & .983 & & \\
\hline $\begin{array}{l}\text { Organizational } \\
\text { Culture }\end{array}$ & .516 & .077 & .522 & & 7.000 .365 & .667 & .751 & $.315 \quad .217$ \\
\hline Human Capital & .252 & .078 & .252 & & 2.001 .099 & .405 & .726 & $.158 \quad .104$ \\
\hline
\end{tabular}

a. Dependent Variable: Innovation Performance Growth.

\section{Conclusion}

This study assessed the innovation practices amongst the SMEs, in order to enhance their business growth performance in the Malaysian market. It was for this reason that data from a sample of 413 respondents from SMEs in the construction, service and manufacturing sectors was collected by means of a structured 
questionnaire. To meet the research objectives data were analyzed using descriptive statistics, correlation analysis, factor analysis and regression analysis. The objective of this study was accomplished by identifying the relationship between organization culture \& human capital towards innovation performance growth.

The findings indicated that the independent variables (organization culture \& human capital) statistically significantly predict the dependent variable (innovation performance growth). The model was considered good with adjusted R2 at 0.575 signifying that $57.5 \%$ of the variability in innovation performance growth has been explained by human capital, and organizational culture. The standardized coefficients showed that organizational culture has the standardized coefficient with the largest absolute valve which explains the greatest amount of the unique variance i.e. organizational culture has the strongest coefficient. These findings were in line with that of Halim, Ahmad, Ramayah, Hanifah, Taghizade and Mohamad 2014 findings a crucial part of innovativeness is the cultural openness to innovation which is evidenced by the connection of organizational culture and organizational learning with innovation. Also in line with the Halim, Ahmad, Ramayah, Hanifah, Taghizade and Mohamad 2015; skerlavaj, song \& lee 2010 studies which concluded that it's very important for organizations to develop/increase their innovative organizational culture in other for the employees to be alert, creative \& innovative to drive the organization. Malaysian SMEs management are attentive to the role innovation plays in SMEs growth. On the other hand, resources are limited making it difficult for them to get involved in R\&D let alone acquiring new \& advanced technologies. Thus, it is recommended that Malaysian government should get more involved \& put strategies in place that will help to promote the SME's so as to reach their maximum level of innovation performance which will contribute tremendously towards to the development of Malaysia economic growth (Saunila, 2014). It is hoped that with these findings \& recommendations, the concept of innovation performance and ways in which it can contribute positively towards enhancing the performance of an organization, through the level of organization culture \& human capital in order to sustain a progressive business performance growth can be attained.

The researcher encountered limitations in this studies like any other studies. The main limitation was as a result of language barrier and racial differences which affected the response rate of the data collection. This study was limited to a specific area i.e. four locations in the north, south, east and west Malaysia and to a specific firm size (small and medium-sized firms), as well as findings were limited to just 3 sectors of SMEs in Malaysia therefore result might not be generalized to all SMEs in Malaysia. As such these limitations creates opportunities for future studies to be explore.

\section{Acknowledgments}

The authors would like to thank the Universiti Sultan Zainal Abidin for their support in this research.

\section{References}

Abdul Hamid, N. A., \& Tasmin, R. (2013). The Relationship of Business Innovation Capabilities and Technology Innovation Capabilities on SME Organization Performance: A Conceptual Framework. Faculty of Technology Management and Business, Universiti Tun Hussein Onn, Batu Pahat, Malaysia.

Abdulsaleh, A. M., \& Worthington, A. C. (2013). Small And Medium-Sized Enterprises Financing: A Review Of Literature. International Journal of Business and Management, 8(14), 36. https://doi.org/10.5539/ijbm.v8n14p36

Abidin, N. Z., Adros, N. A., \& Hassan, H. (2014). Competitive Strategy and Performance of Quantity Surveying Firms in Malaysia. Journal of Construction in Developing Countries, 19(2), 15.

Alam, S. S., Bhuiyan, A. B., Jani, F. M., \& Wel, C. A. C. (2016). The impact of Innovation on Growth and Performance of Processed Food SMEs in Malaysia. International Journal of Entrepreneurship and Innovation Management, 20(1-2), 61-79. https://doi.org/10.1504/ijeim.2016.075299

Al-Ansari, Y. D. Y. (2014). Innovation Practices as a Path to Business Growth Performance: A Study of Small and Medium Sized Firms in The Emerging UAE Market. Southern Cross University, 2014.

Atalay, M., Anafarta, N., \& Sarvan, F. (2013). The Relationship Between Innovation and Firm Performance: An Empirical Evidence From Turkish Automotive Supplier Industry. Procedia-Social and Behavioural Sciences, 75, 226-235. https://doi.org/10.1016/j.sbspro.2013.04.026

Aziz, S. A., \& Mahmood, R. (2011). The Relationship Between Business Model and Performance of Manufacturing Small and Medium Enterprises in Malaysia. African Journal of Business Management, 5(22), 8918. https://doi.org/10.5897/ajbm11.474

Babalola, S. S., \& Omobowale, A. O. (2012). The Role of Trust, Innovation and Knowledge Management in 
Entrepreneurial Survival Strategies: A Study of Selected Cybercafé Micro-Entrepreneurs in Ibadan, Nigeria. Journal of Humanities and Social Sciences, 4(2), 128-136.

Brislin, R. W. (1970). Back translation for cross-cultural research. Journal of Cross-cultural Psychology, 1, 185-216. http://dx.doi.org/10.1177/135910457000100301

Ciesielska, M., \& Iskoujina, Z. (2012). Trust as a success factor in open innovation. The case of Nokia and Gnome. Managing Dynamic Technology-Oriented Business: High-Tech Organizations and Workplaces. Information Science Reference, 11-29. https://doi.org/10.4018/978-1-4666-1836-7.ch002

Dastgerdi. (2012). SMEs Scale of Performance. Journal of Small Business and Enterprise Development, 4(2), 16.

Fard, F. S., Mansor, N. N. A., Mohamed, A., \& Bahru, J. (2011). The Critical Success Factors of Performance Measurement for Malaysian SMEs in Manufacturing Sectors: A Proposed Framework. In Proceeding of the 2nd International Conference on Business and Economic Research.

Ferri, K. \& Mohd, R. (2012). Logistics Efficiency and Firm Performance: Evidence from Indonesian Small and Medium Enterprises. American International Journal of Contemporary Research.

Halim, H. A., Ahmad, N. H., Ramayah, T., Hanifah, H., Taghizadeh, S. K., \& Mohamad, M. N. (2014). The impact of external environmental on business process management and organizational performance. Service Business, 8(4), 559-586. https://doi.org/10.1007/s11628-013-0207-9.

Halim, H. A., Ahmad, N. H., Ramayah, T., Hanifah, H., Taghizadeh, S. K., \& Mohamad, M. N. (2015). Towards an Innovation Culture: Enhancing Innovative Performance of Malaysian SMEs. Academic Journal of Interdisciplinary Studies, 4(2), 85. https://doi.org/10.5901/ajis.2015.v4n2p85

Harry, B., \& Mita, B. (2016). Promotion of Innovation and Job Growth in Small-and Medium-Sized Enterprises in Australia: Evidence and Policy Issues. Australian Economic Review, 49(2), 192-199.

Hussain, J., Ismail, K., \& Shah, F. A. (2015). The Effect of Market and Entrepreneurial Orientations on Organizational Performance: Study of Malaysian SMEs. City University Research Journal.

Hutter, K., Hautz, J., Repke, K., \& Matzler, K. (2013). Open Innovation in Small and Micro Enterprises. Problems and Perspectives in Management, 11(1), 12-22.

Kafetzopoulos, D., \& Psomas, E. (2015). The Impact of Innovation Capability on the Performance of Manufacturing Companies: The Greek case. Journal of Manufacturing Technology Management, 26(1), 104-13. https://doi.org/10.1108/jmtm-12-2012-0117

Khalili, H., Nejadhussein, S., \& Fazel, A. (2013). The influence of entrepreneurial orientation on innovative performance: Study of a petrochemical company in Iran. Journal of Knowledge-based Innovation in China, 5(3), 262-278. https://doi.org/10.1108/jkic-09-2013-0017

Khalique, M., Isa, A. H. B. M., Shaari, N., Abdul, J., \& Ageel, A. (2011). Challenges Faced by the Small and Medium Enterprises (SMEs) in Malaysia: an Intellectual Capital Perspective. International Journal of Current Research, 33(6), 398.

Kmieciak, R., Michna, A., \& Meczynska, A. (2012). Innovativeness, empowerment and IT capability: evidence from SMEs. Industrial Management \& Data Systems, 112(5), 707-728. https://doi.org/10.1108/02635571211232280

Koe, W. L., \& Majid, I. A. (2013). Sustainable Entrepreneurship among Small and Medium Enterprises (SMEs) in Malaysia. International Journal of Economics, Finance and Management, 2(4), 286-290.

Kraus, S., Kauranen, I., \& Henning Reschke, C. (2012). Identification of domains for a new conceptual model of strategic entrepreneurship using the configuration approach. Management Research Review, 34(1), 58-74. https://doi.org/10.1108/01409171111096478

Kreiser, P. M., Marino, L. D., Dickson, P., \& Weaver, K. M. (2010). Cultural influences on entrepreneurial orientation: The impact of national culture on risk taking and proactiveness in SMEs. Entrepreneurship Theory and Practice, 34(5), 959-983. https://doi.org/10.1111/j.1540-6520.2010.00396.x

Kreiser, P. M., Marino, L. D., Kuratko, D. F., \& Weaver, K. M. (2013). Disaggregating entrepreneurial orientation: the non-linear impact of innovativeness, proactiveness and risk-taking on SME performance. Small Business Economics, 40(2), 273-291. https://doi.org/10.1007/s11187-012-9460-x

Kuswantoro, F. (2012). Impact of distribution channel innovation on the performance of small and medium 
enterprises. International Business and Management, https://doi.org/10.3968/j.ibm.1923842820120501.1025

Madhoushi, M., Sadati, A., Delavari, H., Mehdivand, M., \& Mihandost, R. (2011). Entrepreneurial Orientation and Innovation Performance: The Mediating Role of Knowledge Management. Asian Journal of Business Management, 3(4), 310-316.

Maes, J., \& Sels, L. (2014). SMEs' Radical Product Innovation: The Role of Internally and Externally Oriented Knowledge Capabilities. Journal of Small Business Management, 52(1), 141-163. https://doi.org/10.1111/jsbm.12037

Masood. (2013). Innovation and SMEs in Pakistan. Journal of Accounting Performance, 4(1), 11-25.

Naldi, L., Nordqvist, M., Sjöberg, K., \& Wiklund, J. (2007). Entrepreneurial orientation, risk taking, and performance in family firms. Family business review, 20(1), 33-47. https://doi.org/10.1111/j.1741-6248.2007.00082.x

Pirayeh, N., Mahdavi, A. M., \& Nematpour, A. M. (2011). Study of Organizational Culture Influence (based on Denison's model) On Effectiveness Of Human Resources In Karun Oil \& Gas Production Company. Australian Journal of Basic and Applied Sciences, 5(9), 1886-1895.

Rahman, H., \& Ramos, I. (2014). Open innovation in SMEs: Prospects and Challenges. In Information Systems for Small and Medium-sized Enterprises (pp. 313-335). Springer Berlin Heidelberg. https://doi.org/10.1007/978-3-642-38244-4_16

Rahman, M., \& Ramos, I. (2013). Challenges in Adopting Open Innovation Strategies in SMEs: an Exploratory Study in Portugal. Issues in Informing Science and Information Technology, 10, 431-448.

Rauch, A., Wiklund, J., Lumpkin, G. T., \& Frese, M. (2009). Entrepreneurial orientation and business performance: An assessment of past research and suggestions for the future. Entrepreneurship theory and practice, 33(3), 761-787. https://doi.org/10.1111/j.1540-6520.2009.00308.x

Rosli, M. M., \& Sidek, S. (2013). The Impact of Innovation on the Performance of Small and Medium Manufacturing Enterprises: Evidence from Malaysia. Journal of Innovation Management in Small \& Medium Enterprises, 2013. https://doi.org/10.5171/2013.885666

Sabouri, M. S., Ghobakhloo, M., Hong, T. S., \& Zulkifli, N. (2011). Information Technology Adoption in Small and Medium-Sized Enterprises; An Appraisal of two Decades literature. Interdisciplinary Journal of Research in Business, 1(7), 53-80.

Salikin, N., Ab Wahab, N., \& Muhammad, I. (2014). Strengths and Weaknesses among Malaysian SMEs: Financial Management Perspectives. Procedia-Social and Behavioural Sciences, 129, 334-340. https://doi.org/10.1016/j.sbspro.2014.03.685

Sattari. (2013). Identification of Innovative Marketing Strategies to Increase the Performance of Small and Medium Enterprises in Iran. International Journal of Fundamental Psychology and Social Sciences, 3(2), 26.

Saunila, M., \& Ukko, J. (2012). A Conceptual Framework for the Measurement of Innovation Capability and its Effects. Baltic Journal of Management, 7(4), 355-375. https://doi.org/10.1108/17465261211272139

Saunila, M., Pekkola, S., \& Ukko, J. (2014). The Relationship between Innovation Capability and Performance: The Moderating Effect of Measurement. International Journal of Productivity and Performance Management, 63(2), 234-249. https://doi.org/10.1108/IJPPM-04-2013-0065

Saunila. (2014). Innovation Capability and Measurements. Journal of Innovation and Entrepreneurship, 4(1), 6-19.

Schiuma, G. \& Moustaghfir, K. (2013). Knowledge, learning, and Innovation: Research and Perspectives. Journal of Knowledge Management, 17(4), 495-510.

Sekaran, U., \& Bougie, R. (2010). Research methods for business. John Wiley \& Sons.

Škerlavaj, S., \& Lee. (2010). Organizational learning culture, innovative culture and innovations in South Korean firms. Expert Systems with Applications, 37, 6390-6403. https://doi.org/10.1016/j.eswa.2010.02.080.

Sun, H., Wong, S. Y., Zhao, Y., \& Yam, R. (2012). A Systematic Model for Assessing Innovation Competence of Hong Kong/China Manufacturing Companies: A Case Study. Journal of Engineering and Technology 
Management, 29(4), 546-565. https://doi.org/10.1016/j.jengtecman.2012.03.005

Vahter, P., Love, J. H., \& Roper, S. (2012). Openness and Innovation Performance: Are Small Firms Different? CSME Working Paper No. 113. https://doi.org/10.1080/13662716.2015.1012825

Wang, G. L. (2012). A Study of How the Organizational Culture of International Tourist Hotels Affects Organizational Performance: Using Intellectual Capital as the Mediating Variable. Journal of Global Business Management, 8(1), 189.

\section{Copyrights}

Copyright for this article is retained by the author(s), with first publication rights granted to the journal.

This is an open-access article distributed under the terms and conditions of the Creative Commons Attribution license (http://creativecommons.org/licenses/by/4.0/). 